Sains Malaysiana 49(5)(2020): 1107-1114

http://dx.doi.org/10.17576/jsm-2020-4905-15

\title{
Gallic Acid and Methyl Gallate Enhance Antiproliferative Effect of Cisplatin on Cervical Cancer (HeLa) Cells
}

(Asid Galik dan Metil Galat Mempertingkat Kesan Antiproliferatif Cisplatin ke atas Sel Kanser Serviks (HeLa))

\author{
Norlida MAmat*, HaSmah AbDUllah, Hermizi HaPidin \& NoOR FATMAWATI MokHTAR
}

\begin{abstract}
Cervical cancer is the fourth most common cancer-related death affecting women. The drug resistance, toxicities and undesired side effects become the major limitation in cisplatin-based chemotherapy. Gallic acid and methyl gallate are the most abundance phenolic compounds that are widely distributed in plants. This study was conducted to evaluate the antioxidant and antiproliferative activity of gallic acid and methyl gallate and their synergistic effects in combination with cisplatin towards cervical cancer (HeLa) cells. The antioxidant activity of gallic acid and methyl gallate was measured by using 1, 1-diphenyl-2-picrylhydrazyl radical (DPPH) scavenging assay. Antiproliferative activity of gallic acid, methyl gallate and cisplatin on HeLa and NIH/ $3 T 3$ cells was determined using MTT assay. The effect of gallic acid and methyl gallate combined with cisplatin were then determined by CompuSyn software. Gallic acid and methyl gallate showed strong antioxidant activity with $E C_{50}$ value of $18.23 \mu M$ and $19.39 \mu M$, respectively. The $I C_{50}$ of gallic acid, methyl gallate and cisplatin on HeLa cells were $13.44 \mu \mathrm{g} / \mathrm{mL}, 16.55 \mu \mathrm{g} / \mathrm{mL}$, and $8.04 \mu \mathrm{g} / \mathrm{mL}$ whereas in $\mathrm{NIH} / 3 \mathrm{T3}$ cells were $32.90 \mu \mathrm{g} / \mathrm{mL}, 35.70 \mu \mathrm{g} / \mathrm{mL}$, and $6.57 \mu \mathrm{g} / \mathrm{mL}$. Cisplatin combined with fixed concentration of gallic acid and methyl gallate could inhibit the proliferation of HeLa cells greater than cisplatin alone. Interestingly, gallic acid and methyl gallate in combination with cisplatin at the concentration of 0.51-4.02 $\mu \mathrm{g} /$ $m L$ have shown synergistic effects. Therefore, our study suggested that gallic acid and methyl gallate in combination with cisplatin have the potential to be developed as chemotherapeutic agents for cervical cancer.
\end{abstract}

Keywords: Antioxidant activity; antiproliferative activity; gallic acid; methyl gallate; synergistic effect

ABSTRAK

Kanser serviks merupakan kanser keempat yang paling kerap dihidapi dalam kalangan wanita. Faktor kerintangan, kesan toksik dan kesan sampingan yang tidak diingini mengehadkan penggunaan cisplatin dalam rawatan kanser. Asid galik dan metil galat merupakan fenolik yang paling banyak ditemui dalam tumbuhan. Kajian ini dijalankan untuk menilai aktiviti antioksidan dan akiviti antiproliferatif asid galik dan metil galat dan kesan sinergi kombinasinya dengan cisplatin ke atas sel kanser serviks (HeLa). Aktiviti antioksidan asid galik dan metil galat ditentukan dengan asai hapus-sisa radikal bebas DPPH. Manakala aktiviti antiproliferatif ke atas sel HeLa dan NIH/3T3 ditentukan melalui asai MTT. Kesan kombinasi antara asid galik dan metil galat dengan cisplatin ditentukan dengan perisian CompuSyn. Asid galik dan metil galat menunjukkan aktiviti antioksidan yang kuat dengan nilai EC Fo $_{50}$ ing-masing adalah $18.23 \mu \mathrm{M}$ dan $19.39 \mu \mathrm{M} . \mathrm{IC}_{50}$, bagi asid galik, metil galat dan cisplatin ke atas sel HeLa pula adalah 13.44 $\mu \mathrm{g} / \mathrm{mL}, 16.55 \mu \mathrm{g} / \mathrm{mL}$ dan $8.04 \mu \mathrm{g} / \mathrm{mL}$ manakala pada sel NIH/ 373 adalah $32.90 \mu \mathrm{g} / \mathrm{mL}, 35.70 \mu \mathrm{g} / \mathrm{mL}$ dan $6.57 \mu \mathrm{g} / \mathrm{mL}$. Kombinasi antara cisplatin dan asid galik serta metil galat pada kepekatan tertentu berupaya merencat pertumbuhan sel HeLa dengan lebih cekap berbanding dengan rawatan cisplatin sahaja. Kombinasi asid galik dan metil galat dengan cisplatin pada kepekatan 0.51-4.02 $\mu \mathrm{g} / \mathrm{mL}$ juga telah menunjukkan kesan sinergi. Oleh itu, kombinasi asid galik dan metil galat dengan cisplatin berpotensi untuk dibangunkan sebagai agen rawatan kemoterapi untuk kanser serviks.

Kata kunci: Aktiviti antioksidan; aktiviti antiproliferatif; asid galik; kesan sinergi; metil galat

\section{INTRODUCTION}

Cancer is one of the death-leading causes worldwide and becomes a serious problem affecting human health. Apart from that, cervical cancer is the most common type of cancer among women. According to GLOBOCAN 2012, cervical cancer is the fourth most common cancer in women and the seventh from the overall cancers. It represents about $7.5 \%$ of female cancer deaths which numbered approximately 266,000 deaths from cervical cancer worldwide. Additionally, majority of these cervical cancer deaths mostly occur in less developed regions (Ferlay et al. 2013). It also becomes the leading cause of cancer-related deaths among women in Eastern, Western and Middle Africa; Central America; South-Central Asia and Melanesia (Arbyn et al. 2011). According to Malaysian National Cancer Registry Report 2007-2011, cervical 
cancer was the third common cancer in women with $7.7 \%$ cases and age standardised incidence rate of 7.6 per 100000 . Cervical cancer incidence rate increased from the age of 30 years old and peaked at 65-69 years old. Generally, the incidence was the highest among Chinese, followed by Malays and Indians. The most aetiological factor associated with cervical cancer is human pappilomavirus (HPV) infection which is commonly from HPV type 16 and HPV type 18 (Muhamad et al. 2015). Despite screening and HPV vaccination among women have reduced the incidence and mortality rates in developed country, there are still many young women who are newly diagnosed each year (Gordon et al. 2018).

Cisplatin is a well known chemotherapeutic drug, clinically used to treat various types of cancers. In 1978, cisplatin has been approved by FDA as a leading anticancer drug for several types of cancer including bladder cancer, cervical cancer, ovarian cancer, testicular cancer, non-small cell lung cancer and squamous cell carcinoma of the head \& neck (Purena et al. 2018). Its anticancer effect is mainly achieved through DNA damaging activity, resulting in the DNA adduct formation (Selvi et al. 2017). Cisplatin is given based on its emetogenic potential which is a function of its dose. Cisplatin is considered as having high emetogenic potential at the dose of $\geq 50 \mathrm{mg} / \mathrm{m}^{2}$ and moderate emetogenic potential at $<50$ $\mathrm{mg} / \mathrm{m}^{2}$ (Karpe et al. 2016). Cisplatin has been used either individually or combined with other chemotherapeutic drugs. Currently, the administration of various regimens are given to the cancer patients based on cancer type and the severity of the disease (Higuchi \& Yanagawa 2019).

Although this agent is generally effective, its use has been limited due to its toxicity and resistance by the cancer cells. Cisplatin treatment causes nephrotoxicity, hepatotoxicity, and cardiotoxicity to the patients (Dasari \& Bernard 2014). Therefore, one of the approaches to overcome these problems is combination chemotherapy, in which other therapeutic agents are combined with chemotherapeutic drug. The combination chemotherapy has better effects as it can sensitise cancer response to drugs, act towards cancer through different signalling pathway and lower the drug dose (Qin et al. 2018). In the recent years, there is an increase of interest among researchers to explore the potential of natural antioxidants as therapeutic agents towards cancer and other health problems. Alternative substances from natural product sources with high antioxidant properties are reported to exhibit anticancer activities. These antioxidants may reduce or prevent many side effects contributed by reactive oxygen species generated by chemotherapy (Conklin 2000).

Gallic acid (3,4,5-trihydroxybenzoic acid, GA) and its methyl ester derivative, methyl gallate (methyl 3,4,5-trihydroxybenzoate, MG) as shown in Figure 1 are the common phenolic compounds found in various plants (Farhoosh \& Nystrom 2018). Gallic acid exists in red wine, green tea, strawberries, pineapples, bananas, lemons, gallnuts, sumac, witch hazel, tea leaves, oak bark, and apple peels (Asci et al. 2017). The distribution of methyl gallate on the other hand is mostly abundant in Meliaceae species, Galla Rhois, Rosa rugosa, Terminalia myriocarpa, and Geranium niveum and in maple (Genus acer) leaves, grape seeds, and seed kernels of Mangifera indica L. (Jeon et al. 2016). Various biological activities of GA and MG have been reported in previous studies. GA exhibits antioxidant and antiinflammatory effects by protecting human cells or tissues against oxidative stress (Asci et al. 2017). GA is also reported to have antidiabetic (Oboh et al. 2016) and antimicrobial activity (Chanwithesuk et al. 2007). In addition, antiproliferative effects by GA and MG have been reported in different cell lines (Heidarian 2017; Kamatham et al. 2015; Lu et al. 2010; Nam et al. 2016;). To the best of our knowledge, the antiproliferative effect of gallic acid and methyl gallate combined with cisplatin on HeLa still have not been reported. Thus, in the present study, GA and MG were evaluated for their antioxidant activities. GA and MG combined with chemotherapeutic drug, cisplatin were also evaluated for the antiproliferative effects towards HeLa cancer cells. The combination index (CI) of these combinations were also determined.

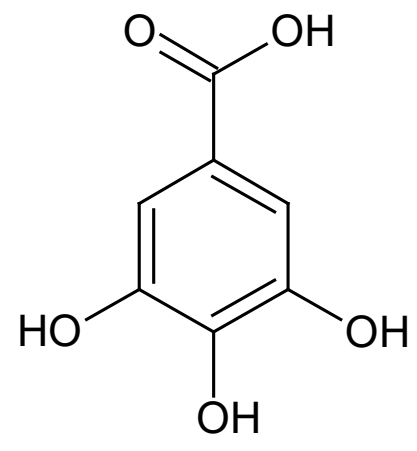

Gallic acid

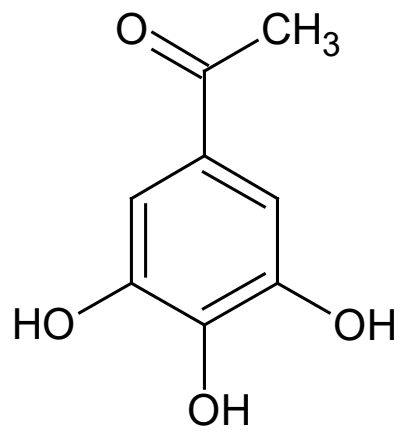

Methyl gallate

FIGURE 1. Chemical structure of gallic acid and methyl gallate 


\section{MATERIALS AND METHODS}

\section{CHEMICALS}

Dulbecco's modified Eagle's medium (DMEM), fetal bovine serum, trypsin, streptomycin, and penicillin were purchased from Gibco Thermo scientific. 3-(4,5-dimethylthiazol-2-yl)-2, 5 diphenyltetrazolium bromide (MTT) was purchased from Nacalai Tesque, Inc. (Japan), dimethyl sulfoxide (DMSO), 2,2-diphenyl-1picrylhydrazyl (DPPH), gallic acid, methyl gallate, and cisplatin were purchased from Sigma Chemical Co. (St. Louis, MO, USA).

\section{1, 1-DIPHENYL-2-PICRYLHYDRAZYL (DPPH) RADICAL SCAVENGING ASSAY}

The color changes of DPPH solution by reducing amount of hydrogen donating compounds was used for evaluating antioxidant activity. The scavenging activity of GA and MG were evaluated based on the method as described by Alma et al. (2003) with slight modification. Briefly, the various concentrations of GA and MG were prepared by diluting the compounds in methanol. $2 \mathrm{~mL}$ of the compounds solution were then added with $2 \mathrm{~mL}$ of $0.3 \mathrm{mM}$ DPPH solution in methanol. The reaction tubes, in triplicates, were wrapped in aluminum foil and kept at room temperature for $30 \mathrm{~min}$ in dark. Then, the absorbance was measured at $517 \mathrm{~nm}$ using a UV-VIS spectrophotometer. Ascorbic acid solution was used as a positive control. The scavenging activity was calculated using the following equation:

$$
\mathrm{DPPH} \text { radical scavenging }(\%)=\left(\frac{\mathrm{A} 1-\mathrm{A} 0}{\mathrm{~A} 1}\right) \times 100
$$

whereby A1 is the absorbance of negative control; and A0 is the absorbance of DPPH solution with sample solution.

\section{CELL CULTURE}

HeLa (ATCC CCL-2) and NIH/3T3 (ATCC CRL-1658) cells were purchased from American Type Culture Collection (ATCC). The HeLa and NIH/3T3 cells used in this study were in passage 10-20. The cell lines were grown in humidified atmosphere under the condition of $37{ }^{\circ} \mathrm{C}$ with $5 \%(\mathrm{v} / \mathrm{v}) \mathrm{CO}_{2}$. The complete medium used for culturing cells was the mixture of DMEM, 10\% FBS and $1 \%$ penicillin-streptomycin.

\section{PREPARATION OF COMPOUND TREATMENTS}

Cisplatin, GA, and MG stock solution $(10 \mathrm{mg} / \mathrm{mL})$ were prepared by diluting $10 \mathrm{mg}$ of compounds in $1 \mathrm{~mL}$ of DMSO. The solution was filtered by using $0.2 \mu \mathrm{L}$ sterile filter unit. The stock solution was then further diluted with culture medium to the different concentrations $(100,50,25,12.5,6.25,3.125,1.56,0.781$, and $0.39 \mu \mathrm{g} /$ $\mathrm{mL})$ prior to use.

\section{CYTOTOXICITY DETERMINATION USING MTT ASSAY} HeLa cells $\left(3 \times 10^{3}\right.$ cells per well $)$ and NIH/3T3 cells $\left(4 \times 10^{3}\right.$ cells per well) were seeded in 96 well plates. The cells were incubated at $37^{\circ} \mathrm{C}$. After $24 \mathrm{~h}$, cells were treated with $100 \mu \mathrm{L}$ of gallic acid, methyl gallate and cisplatin as a positive control at various concentrations $(100,50,25,12.5,6.25,3.125,1.56,0.781$, and 0.391 $\mu \mathrm{g} / \mathrm{mL})$. The treated cells were incubated for 72 hours in $37{ }^{\circ} \mathrm{C} \mathrm{CO}_{2}$ incubator. Then, $10 \mathrm{uL}$ of MTT $(5 \mathrm{mg} /$ $\mathrm{mL}$ in PBS) was added to each well and incubated for additional $4 \mathrm{~h}$ at $37^{\circ} \mathrm{C}$. The culture medium was removed and $100 \mu \mathrm{L}$ of DMSO was added to each well to dissolve the purple-blue formazan crystals. The absorbance (OD) was read at $570 \mathrm{~nm}$ using ELISA reader. $\mathrm{IC}_{50}$ of cisplatin, gallic acid and methyl gallate were calculated from the dose response curve by plotting a graph of percent of cell viability against log concentration. The percentage of cell viability is based on the following formula:

$(\mathrm{OD}$ value of treated cell/OD value of untreated cells $) \times 100$.

\section{ANALYSIS OF SYNERGISTIC EFFECTS}

To determine the combination effects of GA and MG with cisplatin, a non-constant combination treatment of compounds (GA and $\mathrm{MG}$ ) and cisplatin was done following the method as described by Omar et al. (2016) with slight modification. The HeLa cells were treated with cisplatin at various concentrations (8.04, $4.02,2.01,1.01$, and $0.5 \mu \mathrm{g} / \mathrm{mL}$ ) in combination with fixed concentration, $\mathrm{IC}_{50}$ value of $\mathrm{GA}$ at $13.44 \mu \mathrm{g} / \mathrm{mL}$ and $\mathrm{IC}_{50}$ value of MG at $16.55 \mu \mathrm{g} / \mathrm{mL}$. The data from this experiment were analysed using CompuSyn software to determine the combination effects of the drugs combination. The statistical analysis was performed and the results were expressed as combination index (CI). A CI value is a mathematical and quantitative representation of the pharmacological interaction of two drugs $(\mathrm{Cl}>1$ : antagonism; $\mathrm{Cl}=1$ : additive; $\mathrm{CI}<$ : synergism).

\section{STATISTICAL ANALYSIS}

All values were represented as the mean \pm SD. The differences in the mean and $\mathrm{IC}_{50}$ were analysed using Graph Pad Prism version 6. Combination index (CI) of the drug combinations was determined using CompuSyn Software.

\section{RESULTS AND DISCUSSION}

\section{1-DIPHENYL-2-PICRYLHYDRAZYL (DPPH) RADICAL SCAVENGING ASSAY}

Recently, natural antioxidants have attracted great interest among researchers because of their safety properties. GA and its derivatives that belong to the phenolic acids 
group are naturally occurring antioxidants that are widely distributed in plants. They have also been used widely in pharmaceuticals and food industries in which most of them are identified as efficient DPPH radical scavenger (Kalita et al. 2012). Phenolic acids are known as strong antioxidants and can scavenge free radicals due to their hydroxylated molecular properties (Sevgi et al. 2015). Previous study conducted by Karamac et al. (2005) shows that GA is the most effective compound in scavenging the DPPH radicals compared to other phenolic acids compounds. The differences in scavenging activities between these phenolic acids are attributed to the different number of hydroxyl moieties attached to the aromatic ring of the benzoic or cinnamic acid molecules.
Our study showed that GA and MG exhibited very potent anti-radical scavenging activities (Figure 2). Both of the compounds showed concentration-dependent manner in a dose response curve. GA exhibited a slightly higher antioxidant activity with $\mathrm{EC}_{50}$ value of $18.23 \mu \mathrm{M}$ compared to $\mathrm{MG}\left(\mathrm{EC}_{50} 19.39 \mu \mathrm{M}\right)$. The similar findings have also been reported Asnaashari et al. (2014), Kikuzaki et al. (2002), and Lu et al. (2006). The result reveals that although these phenolic acids have the same number of hydroxyl groups, GA with an additional carboxylic group in its molecules is found to be more active than methyl gallate which contains carboxylic acid ester group (Kikuzaki et al. 2002).

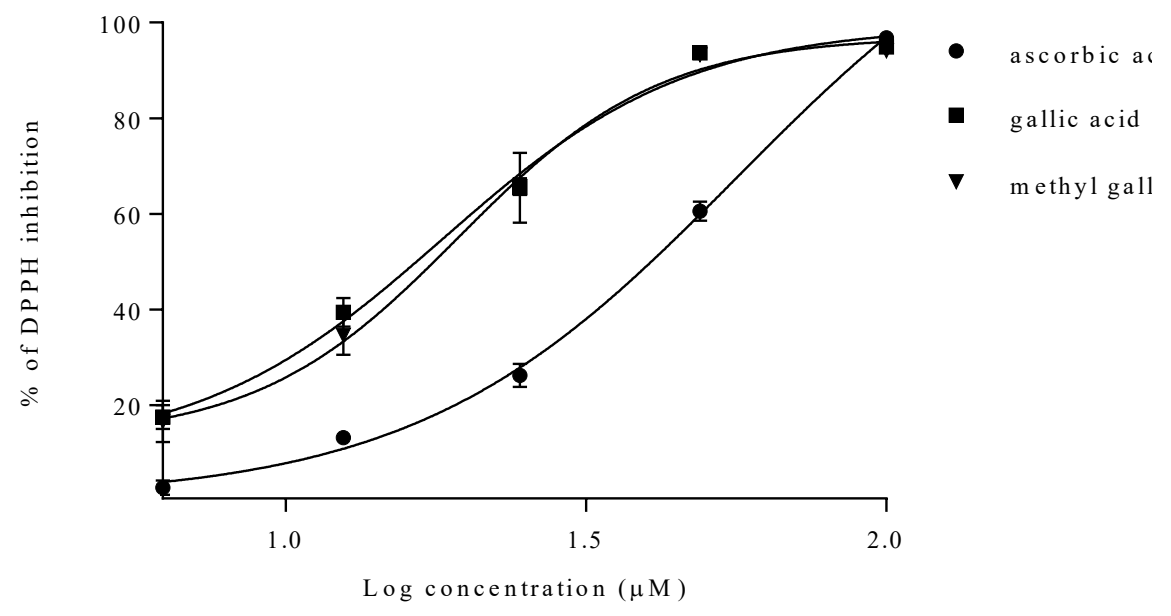

FIGURE 2. DPPH radical scavenging activity of GA and MG at different concentrations. Each value represents the mean $\pm \mathrm{SD}(\mathrm{n}=3)$

\section{CYTOTOXICITY EFFECT}

The antiproliferative activity of GA and MG towards HeLa and NIH/3T3 cells was evaluated using MTT assay. Figure 3 shows the antiproliferative activity of GA, MG and cisplatin as a positive control towards HeLa cells and NIH/3T3 cells. GA and MG were shown to inhibit cell growth of both cancer and normal cells. $\mathrm{HeLa}$ and NIH/3T3 cells growth were inhibited by GA and $\mathrm{MG}$ in a dose-dependent manner. The $\mathrm{IC}_{50}$ of GA, MG, and cisplatin on HeLa were 13.44, 16.55, and 8.04 $\mu \mathrm{g} / \mathrm{mL}$, respectively, whereas in NIH cells the $\mathrm{IC}_{50}$ of $\mathrm{GA}, \mathrm{MG}$ and cisplatin were $32.90,35.70$, and $6.57 \mu \mathrm{g} /$ $\mathrm{mL}$, respectively. The different antiproliferative effects seen in cancer and normal cells indicates that GA and MG exhibit less cytotoxicity effect and are safe in normal $\mathrm{NIH} / 3 \mathrm{~T} 3$ cells compared to HeLa cells. The lower $\mathrm{IC}_{50}$ value of GA and MG may suggest that these compounds could be considered as effective anticancer agents towards HeLa cells. The similar antiproliferative effects of GA on HeLa had also been reported previously (Park 2017; You et al. 2010; Zhao \& Hu 2013).

Over the years, cisplatin is known as an effective antineoplastic agent and has been widely used to treat numerous types of cancer cell. In this study, the low $\mathrm{IC}_{50}$ value of cisplatin in $\mathrm{HeLa}$ and NIH/3T3 cells indicates that cisplatin is not only cytotoxic to cancer cells but it is also harmful to the normal cells. Cisplatin can activate apoptotic pathways and lead to cellular damage in normal tissue through induction of oxidative stress and inflammation. Although many strategies have been developed to overcome this problem, the data and clinical trials are still lacking. Thus, despite inducing organ toxicities and developing cell resistance, cisplatin still remains as the most frequent drug used in cancer treatment (Sun et al. 2019). 
A
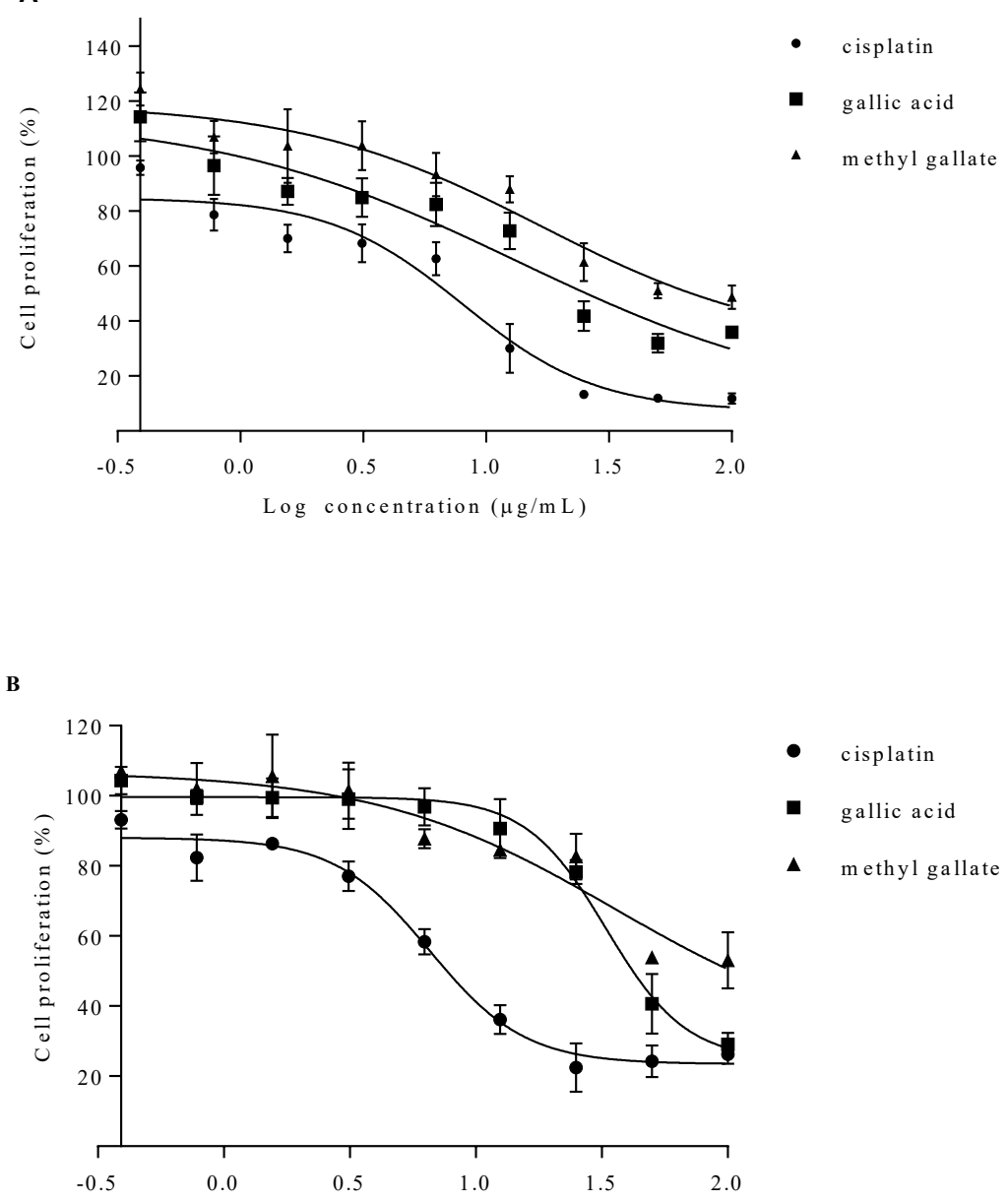

FIGURE 3. Antiproliferative activity of different concentration of GA and MG on HeLa cells (A) and NIH/3T3 cells (B). Each value represents the mean \pm SD from three separate experiments

\section{COMBINATION EFFECTS}

Recently, the new alternative strategy involving the combination of phytochemical compounds and anticancer drugs has been developed. Currently, phytochemicals derived from plants are actively discovered with more than 10,000 phytochemicals have been identified and used in cancer treatment (Tuorkey 2015). The combination of active compounds with anticancer drugs might produce synergistic, antagonistic and additive effects. The beneficial effects of synergism are that this combination strategy could synergise the efficacy of drugs and decrease the drugs dosage; thus can reduce their toxicity (Koraneekit et al. 2018).

In this study, the effect of GA and MG combined with cisplatin on HeLa cells was determined by a nonconstant combination treatment. Serial concentrations of cisplatin were combined with fixed concentration of gallic acid at $13.44 \mu \mathrm{g} / \mathrm{mL}$ and methyl gallate at $16.55 \mu \mathrm{g} /$ $\mathrm{mL}$. Overall, GA in combination with cisplatin inhibited around $70 \%$ of cell proliferation while the combination of MG and cisplatin inhibited $50 \%$ of cell proliferation at all concentrations. Higher cells inhibition was seen in combination of GA and MG compared to cisplatin alone (Figure 4). These combinations effects were then evaluated using CompuSyn Software. Table 1 shows the $\mathrm{Cl}$ values of different combination of GA and MG with cisplatin. The combinations of GA and cisplatin at 0.51 $\mu \mathrm{g} / \mathrm{mL}$ to $4.02 \mu \mathrm{g} / \mathrm{mL}$ demonstrated CI values of less than 1 which were between 0.2626 and 0.4386 , indicating that all these combinations had synergistic effects. The lowest CI value was shown by the combination of GA and cisplatin at $0.51 \mu \mathrm{g} / \mathrm{mL}$. Only the combination of GA and cisplatin at $8.04 \mu \mathrm{g} / \mathrm{mL}$ showed an antagonistic effect with the CI value of 1.014. On the other hand, the different combinations of $\mathrm{MG}$ and cisplatin showed the CI values in between 0.3229 to 1.394 (Table 2). All combinations showed CI values less than 1 except for the combination of $\mathrm{MG}$ and cisplatin at $8.04 \mu \mathrm{g} / \mathrm{mL}$. The lowest CI value was exhibited by the combination of MG and cisplatin at $0.51 \mu \mathrm{g} / \mathrm{mL}$. Greater HeLa cells inhibition was seen in the combination of GA and MG with cisplatin, showing that these combinations could enhance cisplatin's effect. The reported CI values of less than 1 indicate that GA and MG interact synergistically 
with cisplatin, inhibiting HeLa cells' proliferation. These combinations might induce DNA damage in cells and activate the intra-S-phase checkpoint to inhibit DNA synthesis, resulting in apoptosis or cellular senescence. However, further investigation is needed.

GA in combination with cisplatin has been reported to enhance anticancer effect and apoptosis on human small cell lung cancer cells (Wang et al. 2016). This combination is also found to increase tumor cell apoptosis of lung cancer in mice (Kawada et al. 2001). In addition, other study has shown that the combination of MG and cisplatin shows stronger anti-cancer effects on
EL4 murine lymphoma than MG or cisplatin alone (Kim et al. 2016).

However, this in-vitro cytotoxicity study had several limitations. The cultured cells growing in-vitro are not exactly the same as the dissociated replicates of the cells in-vivo. Other factors may affect the cytotoxic effect of the compounds in-vivo such as metabolism and pharmacokinetics in which it is impossible to stimulate these parameters in-vitro. Therefore, it is necessary to further investigate the effect of the compound in future in-vivo study.

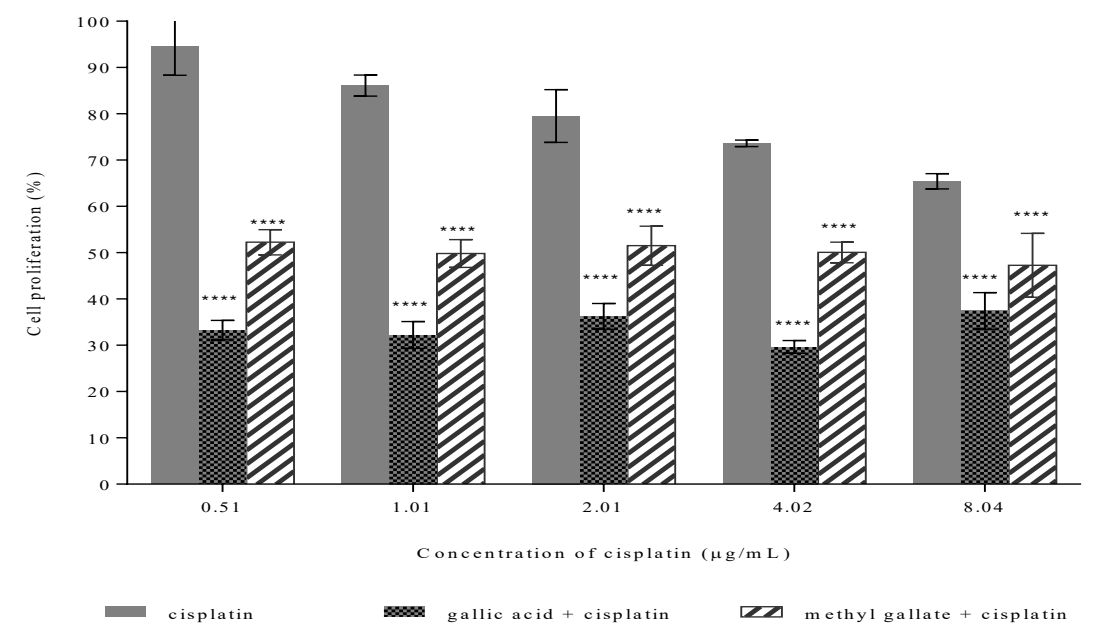

FIGURE 4. The antiproliferative effect of cisplatin alone and cisplatin in combination with GA and MG on HeLa cells. Each value represents mean \pm SD from three separate experiments. $* * * *$ : $p<0.0001$

TABLE 1. CI values for combination effect of cisplatin and GA on HeLa cells

\begin{tabular}{cccc}
\hline Cisplatin dose $(\mu \mathrm{g} / \mathrm{mL})$ & $\begin{array}{c}\text { Gallic acid dose } \\
(\mu \mathrm{g} / \mathrm{mL})\end{array}$ & Effect & 0.2626 \\
\hline 0.51 & 13.44 & 0.6673 & 0.2745 \\
1.01 & 13.44 & 0.6853 & 0.4340 \\
2.01 & 13.44 & 0.6374 & 0.4386 \\
4.02 & 13.44 & 0.7035 & 1.0143 \\
\hline
\end{tabular}

TABLE 2. CI values for combination effect of cisplatin and MG on HeLa cells

\begin{tabular}{cccc}
\hline Cisplatin dose $(\mu \mathrm{g} / \mathrm{mL})$ & $\begin{array}{c}\text { Methyl gallate dose } \\
(\mu \mathrm{g} / \mathrm{mL})\end{array}$ & Effect & CI \\
\hline 0.51 & 16.55 & 0.48 & 0.32297 \\
1.01 & 16.55 & 0.5 & 0.37922 \\
2.01 & 16.55 & 0.48 & 0.58893 \\
4.02 & 16.55 & 0.5 & 0.86786 \\
8.04 & 16.55 & 0.52 & 1.39429 \\
\hline
\end{tabular}




\section{CONCLUSION}

The result of this present study demonstrated that GA and MG in combination with cisplatin synergistically inhibited the growth of HeLa cells even at lower concentration of cisplatin. This finding may suggest that GA and MG are potential sources that can be used in combination with cisplatin for the development of new therapeutic agents for cancer treatment. The outcome of this study also provides the basis for the molecular studies to find the exact mechanism on how the combinations act synergistically towards HeLa cells.

\section{ACKNOWLEDGEMENTS}

This work was funded by Universiti Sains Malaysia Research University Grant (1001/PPSK/8012276).

\section{REFERENCES}

Alma, M.H., Mavi, A., Yildirim, A., Digrak, M. \& Hirata, T. 2003. Screening chemical composition and in vitro antioxidant and antimicrobial activities of the essential oils from Origanum syriacum L. growing in Turkey. Biological and Pharmaceutical Bulletin 26(12): 1725-1729.

Arbyn, M., Castellsague, X., de Sanjose, S., Bruni, M., Saraiya, L., Bray, F. \& Ferlay, J. 2011. Worldwide burden of cervical cancer in 2008. Annals of Oncology 22: 2675-2686.

Asnaashari, M., Farhoosh, R. \& Sharif, A. 2014. Antioxidant activity of gallic acid and methyl gallate in triacylglycerols of Kilka fish oil and its oil-in-water emulsion. Food Chemistry 159: 439-444.

Asci, H., Ozmen, O., Ellidag, Y.H., Aydin, B., Bas, E. \& Yilmat, N. 2017. The impact of gallic acid on the methotrexateinduced kidney damage in rats. Journal of Food and Drug Analysis 25: 890-897.

Conklin, K.A. 2000. Dietary antioxidants during cancer chemotherapy: Impact on chemotherapeutic effectiveness and development of side effects. Nutr. Cancer 37(1): 1-18.

Chanwitheesuk, A., Teerawutgulrag, A., Kilburn, J.D. \& Rakariyatham, N. 2007. Antimicrobial gallic acid from Caesalpinia mimosoides Lamk. Food Chemistry 100: 10441048.

Dasari, S. \& Bernard, P. 2014. Cisplatin in cancer therapy: Molecular mechanisms of action. European Journal of Pharmacology 740: 364-378.

Farhoosh, R. \& Nyström, L. 2018. Antioxidant potency of gallic acid, methyl gallate and their combinations in sun flower oil triacylglycerols at high temperature. Food Chemistry 244: 29-35.

Ferlay, J., Soerjomataram, I., Ervik, M., Dikshit, R., Eser, S., Mathers, C., Rebelo, M., Parkin, D.M., Forman, D. \& Bray, F. 2013. GLOBOCAN 2012 v1.0, Cancer Incidence and Mortality Worldwide: IARC CancerBase No. 11 [Internet]. Lyon: International Agency for Research on Cancer. World Health Organization.

Gordon, C., Carmichael, J.C. \& Tewari, K.S. 2018. Gynecologic Oncology Reports Oncofertility in the setting of advanced cervical cancer - A case report. Gynecologic Oncology Reports 24: 27-29.

Heidarian, E., Keloushadi, M., Ghatreh-samani, K. \& Jafaridehkordi, E. 2017. Gallic acid inhibits invasion and reduces IL-6 gene expression, pSTAT3, pERK1/2, and pAKT cellular signaling proteins in human prostate cancer DU-145 cells International Journal of Cancer Management 10(11):

Higuchi, K. \& Yanagawa, T. 2019. Evaluating dose of cisplatin responsible for causing nephrotoxicity. PLOS ONE 14(4): e0215757.

Jeon, M., Rahman, N. \& Kim, Y. 2016. Wnt/ $\beta$-catenin signaling plays a distinct role in methyl gallate-mediated inhibition of adipogenesis. Biochemical and Biophysical Research Communications 479: 22-27.

Kalita, D., Kar, R. \& Handique, J.G. 2012. A theoretical study on the antioxidant property of gallic acid and its derivatives. Journal of Theoretical and Computational Chemistry 11(2): 391-402.

Kamatham, S., Kumar, N. \& Gudipalli, P. 2015. Isolation and characterization of gallic acid and methyl gallate from the seed coats of Givotia rottleriformis Griff. and their antiproliferative effect on human epidermoid carcinoma A431 cells. Toxicology Reports 2: 520-529.

Karamac, M., Kosinska, A. \& Pegg, R.B. 2005. Comparison of radical-scavenging activities for selected phenolic acids. Polish Journal of Food and Nutrition Science 14(2): 165-170.

Karpe, A., Patil, V.M., Joshi, A., Noronha, V., Gupta, S., Ramaswamy, A., Sahu, A., Doshi, V., Gupta, T., Rath, S., Banavali, S. \& Prabhash, K. 2016. Weekly cisplatin (30-40 $\mathrm{mg} / \mathrm{m} 2$ ) as radiosensitizer: Is it high or moderate emetic agent? Indian Journal of Cancer 53(3): 454-456.

Kawada, M., Ohno, Y., Ri, Y., Ikoma, T., Yuugetu, H., Asai, T., Watanabe, M., Yasuda, N., Akao, S., Takemura, G., Minatoguchi, S., Gotoh, K., Fujiwara, H. \& Fukuda, K. 2001. Anti-tumor effect of gallic acid on LL-2 lung cancer cells transplanted in mice. Anti-Cancer Drugs 12(10): 847-852.

Kikuzaki, H., Hisamoto, M., Hirose, K., Akiyama, K. \& Taniguchi, H. 2002. Antioxidant properties of ferulic acid and its related compounds. Journal of Agricultural and Food Chemistry 50: 2161-2168.

Kim, H., Lee, G., Sohn, S., Lee, C., Kwak, J.W. \& Bae, H. 2016. Immunotherapy with methyl gallate, an inhibitor of Treg cell migration, enhances the anti-cancer effect of cisplatin therapy. Korean Journal of Physiology and Pharmacology 20(3): 261-268.

Koraneekit, A., Limpaiboon, T., Sangka, A., Boonsiri, P., Daduang, S. \& Daduang, J. 2018. Synergistic effects of cisplatin-caffeic acid induces apoptosis in human cervical cancer cells via the mitochondrial pathways. Oncology Letters 15: 7397-7402.

Lu, Z., Nie, G., Belton, P.S., Tang, H. \& Zhao, B. 2006 Structure-activity relationship analysis of antioxidant ability and neuroprotective effect of gallic acid derivatives. Neurochemistry International 48: 263-274.

Lu, Y., Jiang, F., Jiang, H., Wu, K., Zheng, X., Cai, Y., Katakowski, M., Chopp, M. \& To, S.T. 2010. Gallic acid suppresses cell viability, proliferation, invasion and angiogenesis in human glioma cells. European Journal of Pharmacology 641: 102-107.

Malaysian National Cancer Registry Report 2007-2011. 2016. Ministry of Health, Malaysia.

Muhamad, N.A., Kamaluddin, M.A., Adon, M.Y., Noh, M.A., Bakhtiar, M.F., Tamim, N.S.I., Mahmud, S.H. \& Aris, T. 2015. Survival rates of cervical cancer patients in Malaysia. Asian Pacific Journal of Cancer Prevention 16(7): 3067-3072.

Nam, B., Rho, K.J., Shin, D. \& Son, J. 2016. Gallic acid induces apoptosis in EGFR-mutant non-small cell lung cancers 
by accelerating EGFR turnover. Bioorganic \& Medicinal Chemistry Letters 26: 4571-4575.

Oboh, G., Ogunsuyi, O.B., Ogunbadejo, M.D. \& Adefegha, S.A. 2016. Influence of gallic acid on $\alpha$-amylase and $\alpha$ -glucosidase inhibitory properties of acarbose. Journal of Food and Drug Analysis 24: 627-634.

Omar, W.A.W., Azhar, N.A., Fadzilah, N.H. \& Nik Mohamed Kamal, N.N.S. 2016. Bee pollen extract of Malaysian stingless bee enhances the effect of cisplatin on breast cancer cell lines. Asian Pacific Journal of Tropical Biomedicine 6(3): 265-269.

Park, W.H. 2017. Gallic acid induces HeLa cell death via increasing GSH depletion rather than ROS levels. Oncology Reports 37: 1277-1283.

Purena, R., Seth, R. \& Bhatt, R. 2018. Protective role of Emblica officinalis hydro-ethanolic leaf extract in cisplatin induced nephrotoxicity in rats. Toxicology Reports 5: 270-277.

Qin, S., Cheng, Y., Lei, Q., Zhang, A. \& Zhang, X. 2018. Combinational strategy for high-performance cancer chemotherapy. Biomaterials 171: 178-197.

Selvi, S.K., Vinoth, A., Varadharaian, T., Weng, C.F. \& Padma, V.V. 2017. Neferine augments therapeutic efficacy of cisplatin through ROS-mediated non-canonical autophagy in human lung adenocarcinoma (A549 cells). Food and Chemical Toxicology 103: 28-40.

Sevgi, K., Tepe, B. \& Sarikurkcu, C. 2015. Antioxidant and DNA damage protection potentials of selected phenolic acids. Food and Chemical Toxicology 77: 12-21.

Sun, C., Zhang, Q., Zheng, G. \& Feng, B. 2019. Phytochemicals: Current strategy to sensitize cancer cells to cisplatin. Biomedicine \& Pharmacotherapy 110: 518-527.

Tuorkey, M.J. 2015. Cancer therapy with phytochemicals: Present and future perspectives. Biomedical and Environmental Sciences 28(11): 808-819.

Wang, R., Ma, L., Weng, D., Yao, J., Liu, X. \& Jin, F. 2016. Gallic acid induces apoptosis and enhances the anticancer effects of cisplatin in human small cell lung cancer H446 cell line via the ROS-dependent mitochondrial apoptotic pathway. Oncology Reports 35: 3075-3083.

You, B.R., Moon, H.J., Han, Y.H. \& Park, W.H. 2010. Gallic acid inhibits the growth of HeLa cervical cancer cells via apoptosis and/or necrosis. Food and Chemical Toxicology 48: $1334-1340$

Zhao, B. \& Hu, M. 2013. Gallic acid reduces cell viability, proliferation, invasion and angiogenesis in human cervical cancer cells. Oncology Letters 6: 1749-1755.

Norlida Mamat

Faculty of Health Sciences

Gong Badak Campus

Universiti Sultan Zainal Abidin

21300 Kuala Nerus, Terengganu Darul Iman

Malaysia

Norlida Mamat, Hasmah Abdullah \& Hermizi Hapidin

School of Health Sciences

Health Campus

Universiti Sains Malaysia

16150 Kubang Kerian, Kelantan Darul Naim

Malaysia

Noor Fatmawati Mokhtar

Institute for Research in Molecular Medicine (INFORMM)

Health Campus

Universiti Sains Malaysia

16150 Kubang Kerian, Kelantan Darul Naim

Malaysia

*Corresponding author; email: norlida@unisza.edu.my

Received: 23 April 2019

Accepted: 15 January 2020 